\title{
TOWARDS THE PRODUCTION OF HIGH PERFORMANCE AUTOCLAVED BINDING PRODCTS FROM INDUSTRIAL SOLID WASTES
}

\author{
Abo-El-Enein, S. A. ${ }^{(1)}$; El-Gamal, Safaa, M. A..$^{(1)}$; Osman, T. A. ${ }^{(2)}$; \\ Khater, H. M. ${ }^{(2)}$ and Zarad, Omima, M. \\ 1) Chemistry Department, Faculty of Science, Ain shams University, Egypt \\ 2) Housing and Building National Research Center, Egypt
}

\begin{abstract}
The object of this investigation is to study the possible production of autoclaved building products using several industrial solid wastes, produced as by-products from certain industries, as pozzolanic materials activated using alkaline activators namely, cement kiln dust (CKD) and hydrated lime $[\mathrm{Ca}(\mathrm{OH}) 2]$. The ground granulated blast-furnace slag (GGBFS)-cement kiln dust (CKD) mixes were made with and without nano-metakaolin (NMK) and silica fume (SF) as additives. The four dry mixtures were prepared and subjected to hydrothermal conditions in the autoclave at a pressure of 8 atmospheres of saturated steam for different curing ages of $0.5,2,6,12$ and 24 hours. The autoclaved specimens, thus produced were examined for their chemical and mechanical properties. These specimens are characterized using thermogravimetric analysis (TGA) and scanning electron microscopy (SEM) as well as compressive strength and kinetics of hydration via the determination of chemically combined water (Wn, \%) and free lime contents at different autoclaved ages. From the results obtained it was found that the autoclaved products obtained from the autoclaved pastes with addition silica fume (SF) or nano-metakaolin (NMK) possesses improved physico-chemical and mechanical characteristics. In addition, the extent of enhancement of mechanical properties increases with increasing NMK or SF addition.
\end{abstract}

Keywords: Ground granulated slag, Silica fume, Pozzolanic reaction, Cement Kiln dust, Nano-metakaolin 
J. Environ. Sci.

Institute of Environmental Studies and Research - Ain Shams University

\section{INTRODUCTION}

Manufacturing of Portland cement is a resource exhausting, energy intensive process that releases large amounts of the green house gas $\mathrm{CO} 2$ into the atmosphere. In this study the possible production of autoclaved building products using several industrial solid wastes, produced as by-products from certain industries, as pozzolanic materials activated by two alkaline activators. The alkaline activators used are cement kiln dust (CKD) (the solid waste produced from cement industries using the "dry process") and hydrated lime $[\mathrm{Ca}(\mathrm{OH}) 2]$.

Pozzolana is a natural or artificial material containing silica in a reactive form. A more formal definition of (ASTM specification C618, 2001) describes Pozzolana as a siliceous or siliceous and aluminous material which in itself possesses little or no cementitious value but will in finely divided form and in the presence of moisture, chemically reacts with calcium hydroxide at ordinary temperatures to form hydrated cementitious properties (Singh and Garg, 2006) and (Tseng et al., 2005).It is important to remember that the pozzolanic reaction, like other chemical reaction, can be accelerated by temperature and chemical accelerators such as alkalis and sulfate (Shi and Day, 1995). The use of pozzolanic materials as a blended component is generally associated with significant savings in energy and reducing the solid wastes (Heikal, 2000).

Metakaolin (MK) is a pozzolanic material. It is a dehydroxylated form of the clay mineral kaolinite. It is combined by calcination of kaolinite clay at temperature between $500^{\circ} \mathrm{C}$ and $800^{\circ} \mathrm{C}$. Between 100 and $200^{\circ} \mathrm{C}$, clay 
minerals lose most of their adsorbed water. Between 500 and $800^{\circ} \mathrm{C}$ kaolinite becomes calcined by losing water through dehydroxillization. The raw material input in the manufacture of $\mathrm{MK}(\mathrm{Al} 2 \mathrm{Si} 2 \mathrm{O} 7)$ is kaolin clay. Kaolin is a fine, white, clay mineral that has been used in the manufacture of porcelain. Kaolinite is the mineralogical term that is applicable to kaolin clays. Kaolinite is defined as a common mineral, hydrated aluminium disilicate, the most common constituent of kaolin, Siddique and Khan, (2011).

Silica fume is a pozzolanic material, which is a by-product of the silicon smelting process. It is used to produce silicon metal and ferrosilicon alloys by reducing quartz in an electric arc furnace. Silica fume is characterized by its small spherical particles, very high surface area and have a high content of glassy phase silicon dioxide ( $\mathrm{SiO} 2)$. The results of physico-chemical investigation and microstructure of the hydrated blended cement containing silica fume, indicated that it is a highly active Pozzolana and increases the resistance to sulfate attack for cement pastes (Massazza, 2003).

Shoukry, et al., (2013), studied the effect of NMK on properties of fiber reinforced cement. Different percentages of NMK ranging from $2 \%$ to $14 \%$ were used with the replacement of cement keeping constant fiber content of 2 $\%$ for developing fiber reinforced nano-cementitious composite. Additional increase in the flexural strength by about $67 \%$ was achieved at $10 \%$ NMK content. The capillary water absorption generally decreases with increasing replacements of cement by NMK. A decrease of about $50 \%$ was observed at $10 \%$ NMK. 
Abo El-Enein, et al., (2014) and Mory, et al., (2010), prepared (NMK) nano metakaolin by firing of nano kaolinite clay (NK) at different temperature $\left(750-825^{\circ} \mathrm{C}\right)$ for $2 \mathrm{hr}$. the pozzolanic activity of (NMK) samples was studied using hydrated lime as an activator. The optimum firing temperature was established from the results of hydration kinetics and differential scanning calorimetry (DSC) and found to be $750^{\circ} \mathrm{C}$. The produced nano metakaolin is designed as NMK (750). This was based on the marked consumption of free $\mathrm{Ca}(\mathrm{OH}) 2$ by $\mathrm{NMK}$ fired at $750^{\circ} \mathrm{C}$ as well as the highest values of chemically combined water at all ages of hydration. Therefore, NMK was used for partial replacement of OPC and studying the physic-mechanical properties of OPC-NMK blended cement pastes.

Srivastava, et al., (2012), stated that, by addition of some pozzolanic materials like SF and MK the various properties of concrete viz, workability, durability, strength, resistance to cracks and permeability can be improved. The use of silica fume in concrete has engineering potential and economic advantage; metakaolin is one of such waste/non-conventional material which can be used in the construction industry. This investigation showed that the optimum doses of SF and MK combination in production of concrete were $6 \%$ and $15 \%$ (by weight) respectively, when used as part replacement of OPC.

Velosa, et al., (2009) and Srinivasu, et al., (2014) proved that the addition of metakaolin (as an artificial pozzolana) improves the mechanical characteristics of lime mortars and contributes towards a higher durability. Mortars with the same volumetric ratio were tested in terms of flexural and 
compressive strength at ages $28 \& 90$ days, and the elasticity was determined. A relation between the mechanical and strength achieved by lime mortars with the addition of metakaolin from different batches and metakaolin mineral and chemical composition was assessed. The influence of metakaolin composition on the strength of the mortars is an important step in improving their performance and extending their application.

\section{MATERIAL AND EXPERIMENTAL TECHNIQUES}

The materials used in this study were ground granulated blast-furnace slag (GGBFS) was obtained from Egyptian Tourah Portland Cement Company. GGBFS is a by-product of iron and steel industry which results from the fusion of limestone with minerals from the coke, siliceous and aluminous residue remaining after the production of iron from the ore, cement kiln dust (CKD) a by-product of cement manufacturing. It formed from electrostatic precipitators during the production of cement clinker using the dry process. CKD was obtained from Suez Cement Company, Suez, Egypt, nano metakaolin (NMK) is prepared by firing of nano kaolin $(\mathrm{NK})$ at different temperatures (750-825oC) for 2 hours and Silica fumes (SF) is a byproduct of silicon or ferrosilicon alloys industries. It was obtained from Ferro-silicon Company, Kom-Ombo, Egypt. The results of chemical analysis of these materials are shown in Table (1).The percentage composition and the designations of each series are given in Table (2). 
J. Environ. Sci.

Institute of Environmental Studies and Research - Ain Shams University

Table(1): Chemical analysis of the used materials

\begin{tabular}{|c|c|c|c|c|}
\hline Oxides, (\%) & GGBFS & CKD & NMK & SF \\
\hline $\mathrm{SiO}_{2}$ & 35.38 & 14.50 & 53.4 & 94.3 \\
\hline $\mathrm{Al}_{2} \mathrm{O}_{3}$ & 8.22 & 3.76 & 34.3 & 0.33 \\
\hline $\mathrm{Fe}_{2} \mathrm{O}_{3}$ & 1.79 & 2.69 & 0.1 & 1.09 \\
\hline $\mathrm{CaO}$ & 42.59 & 49.60 & - & 0.65 \\
\hline $\mathrm{MgO}$ & 6.17 & 1.95 & - & 0.47 \\
\hline $\mathrm{SO}_{3}-$ & 2.74 & 5.23 & - & 0.31 \\
\hline $\mathrm{Cl}^{-}$ & - & 5.84 & - & - \\
\hline $\mathrm{Na}_{2} \mathrm{O}$ & 0.58 & 2.68 & - & 0.35 \\
\hline $\mathrm{K}_{2} \mathbf{O}^{\mathrm{TiO}} \mathbf{O}_{2}$ & 0.49 & 2.19 & - & 0.67 \\
\hline $\mathrm{P}_{2} \mathrm{O}_{5}$ & 0.43 & - & 1.5 & - \\
\hline Free CaO & - & 21.58 & - & - \\
\hline (L.O.I) & 0.84 & 15.60 & 10.3 & 1.76 \\
\hline Total & 99.97 & 99.94 & 99.90 & 99.89 \\
\hline
\end{tabular}

Table(2): Percentage composition of different investigated mixes andtheir designations

\begin{tabular}{|c|c|c|c|c|}
\hline Mix no. & GGBFS & CKD & NMK & SF \\
\hline M1 & 70 & 30 & 5 & \\
\hline M2 & 70 & 30 & 10 & \\
\hline M3 & 60 & 40 & - & 5 \\
\hline M4 & 60 & 40 & - & 10 \\
\hline
\end{tabular}

Each dry mixture was first mixed in the dry state using ethanol for two hours in order to obtain complete homogeneity of the mixture. Ethanol was then evaporated by heating the mixture at $90 \mathrm{C}$ for 3 hours and then kept in air tight containers until the time of paste preparation 
The various cement pastes were prepared by mixing the dry solid mixture with water using the water/solid (W/S) ratios in the range 0.27-0.28 and then cylindrical specimens having $2 \mathrm{~cm}$ diameter and about $2 \mathrm{~cm}$ height were moulded under hydraulic pressure of $50 \mathrm{~kg} / \mathrm{cm} 2$.The moulded specimens were cured at about $100 \%$ relative humidity at room temperature for the first 24 hours to attain the final setting of the specimens. The specimens then dried at $80 \mathrm{oC}$ overnight and kept in a desiccator until the desired time of autoclaving was reached. The specimens of each mixture were cured under hydrothermal conditions in an autoclave at a pressure of 8 atm of saturated steam for $0.5,2,6,12$, and 24 hours. At the end of each autoclaving period, the specimens were removed from the autoclave and dried at 900C for 24 hours to remove the free water.

Three dried cylindrical specimens were used for the determination of the compressive strength after each autoclave period. This test was performed using a Ton industric machine (West Germany) for maximum load of 60 tons. Kinetics of hydration process were studied from the determination of nonevaporable (chemically-combined) water $(\mathrm{Wn}, \%)$ and free lime $(\mathrm{CaO}, \%)$ contents for the hardened specimens. The phase composition of the formed hydrates was investigated by means of thermogravimetric analysis (TGA). The morphology and microstructure of some selected samples were studied using SEM technique. 
J. Environ. Sci.

Institute of Environmental Studies and Research - Ain Shams University

\section{RESULTS AND DISCUSSION}

\section{A. Hydration characteristics and Phase Composition of Autoclaved}

GGBFS-CKD-NMK Specimens: The results of compressive strength, combined water and free lime contents of autoclaved specimens made of mix M1 [(70 \% GGBFS - 30\% CKD) with addition of $5 \% \mathrm{NMK}]$ are graphically plotted as a function of curing time in Fig. (1). The results indicate that, three stage of hydration namely; "the pre-dormant period" during the first 0.5 hours of autoclaved; this is followed by relatively slow step; "dormant period" during 0.5 to 2 hours and "acceleration step" during from 2 to 12 hours where sharp increase in combined water and compressive strength values can be observed. This acceleration step is followed by a gradual increase in compressive strength and combined water up to 24 hours of hydration; this represents the "diffusion step". The free lime content $(\mathrm{CaO}, \%)$ is completely consumed at all age of hydration. It's evident that NMK has very high hydraulic activity as compared to GGBFS; this can be clearly the distinguished from the relative high compressive strength and (Wn, \%) content at all autoclaving ages.

With addition $10 \%$ NMK [mix M2], Fig. (2), the results indicate that, the variations of chemically combined water content $(\mathrm{Wn}, \%)$ and compressive strength values for these specimens are almost similar to those obtained for the hardened specimens made of mixM1; this is due to the same reasons reported earlier in this investigation. Their appeared a complete consumption of free lime content $(\mathrm{CaO}, \%)$ at all age of hydration. This indicate the fast hydrothermal interaction between GGBFS and NMK with the free lime 
content in CKD.

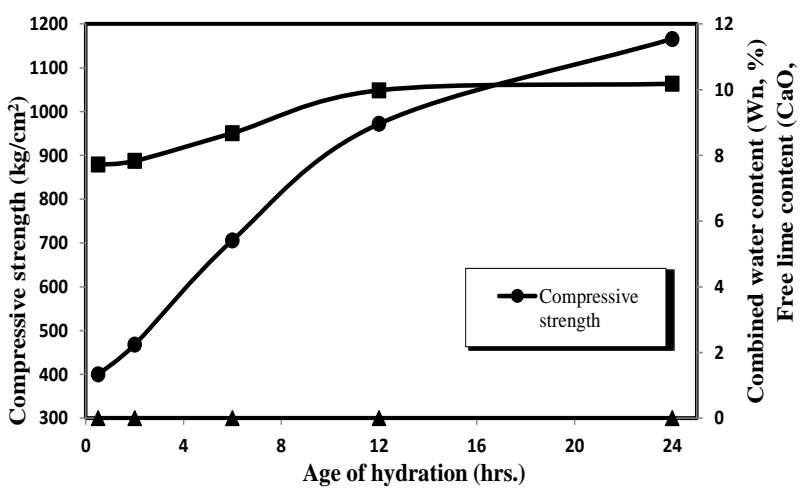

Fig(1): Compressive strength, combined water and free lime of autoclaved specimens made of mix M1.

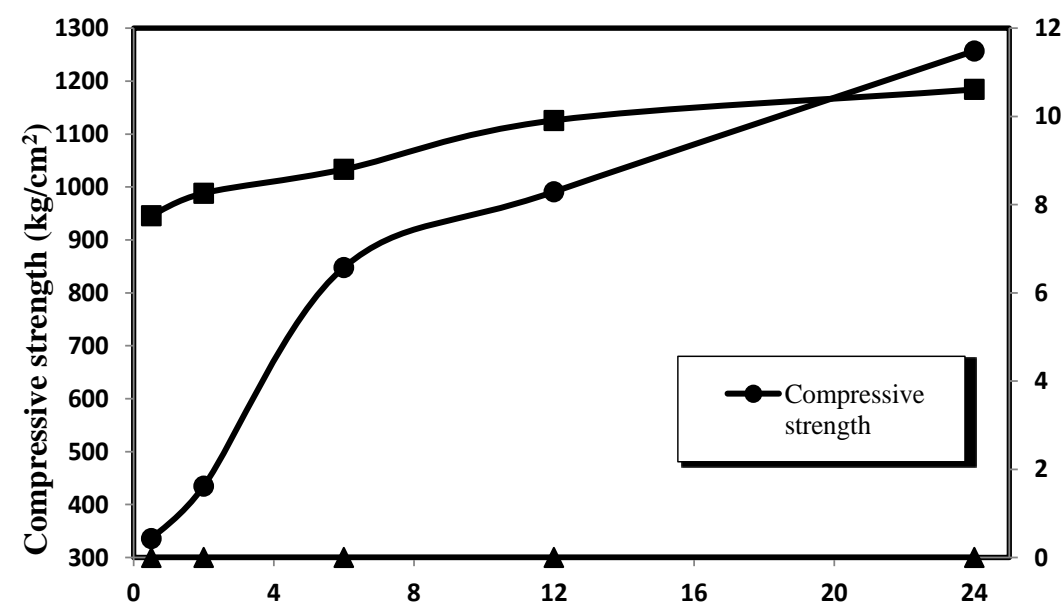

Fig(2): Compressive strength, combined water and free lime of autoclaved specimens made of mix M2. 
Thermogravimetric analysis: Fig. (3) Shows the TGA thermograms of autoclaved specimens made of mix M2, at the hydrothermal ages of 6 and 24 hours. The results indicate that the weight loss of free lime $\mathrm{Ca}(\mathrm{OH}) 2$ of autoclave specimen show a complete consumption at all ages of hydration; meanwhile, the weight loss of $\mathrm{C}-\mathrm{S}-\mathrm{H}$ phases obtained for the autoclave specimens increase with increasing age of steam curing from 6 to 24 hours. This is due to the high alkali content in CKD is sufficient for the pozzolanic reaction of GGBFS and NMK at all ages of autoclaved.

Scanning electron microscopy: The SEM examination of autoclaved specimens made of mix M2during the hydrothermal solidification process at6 and 24 hours, are shown in Fig. (4).The SEM micrographs displayed the increase in the amount of NMK to $10 \%$ as additive in mix M2 resulted in highly dense structure composed of C-S-H phases inducting the role of NMK, as a strong pozzolanic material, leads to increase in the extent of strength improvement of these autoclaved specimens.

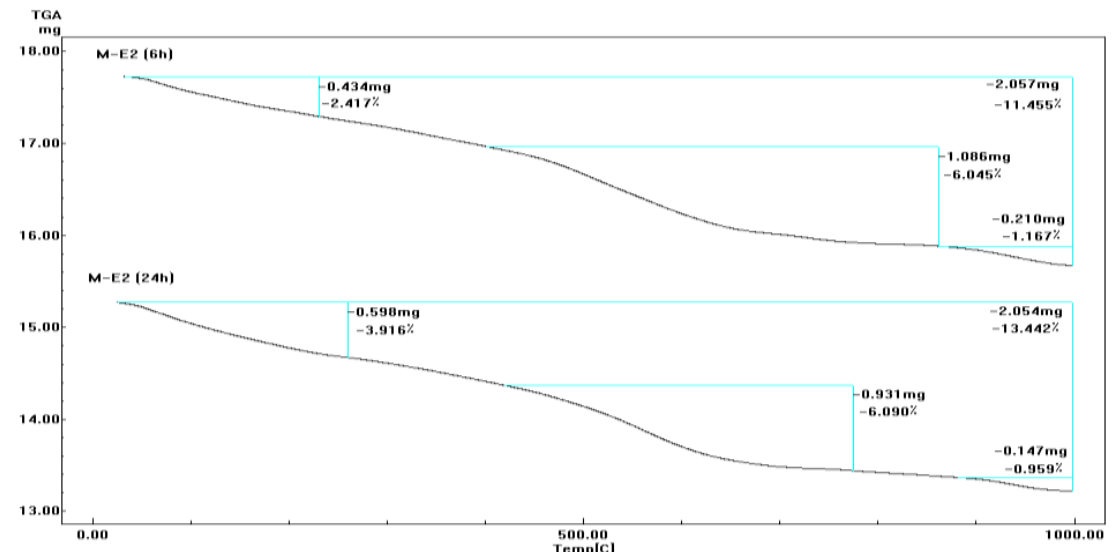

Fig(3): TGA thermograms of autoclaved specimens made of mix M2 after 6 and 24 hours autoclaving 

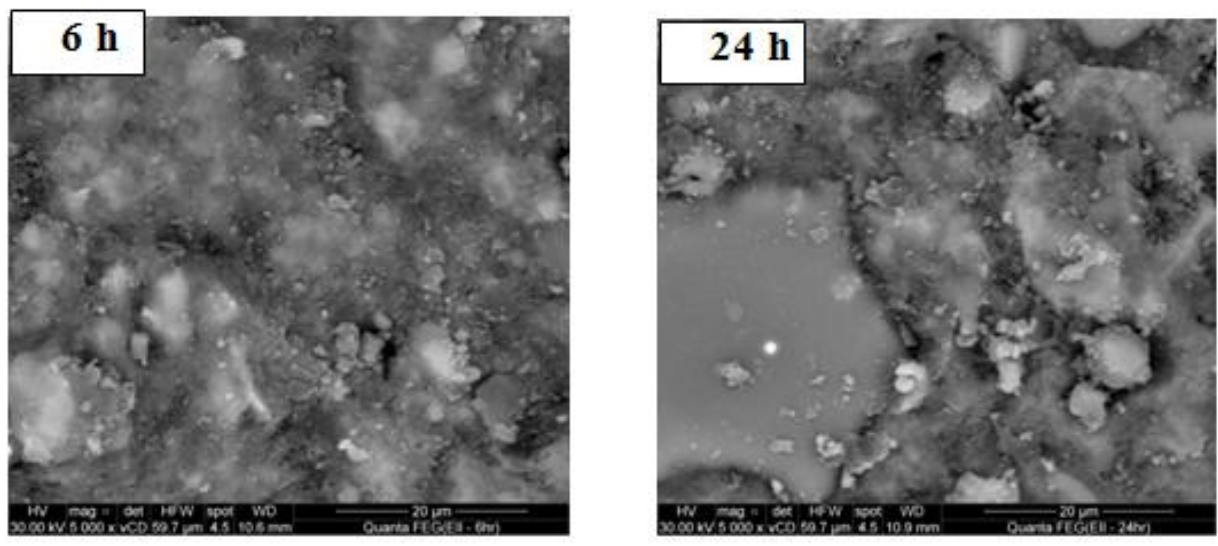

Fig(4): SEM micrographs of autoclaved specimens made of mix M2

\section{B. Hydration Characteristics and Phase Composition of Autoclaved}

GGBFS-CKD-SF Specimens: The results of compressive strength, combined water and free lime contents of autoclaved specimens made of mix M3 [(60\% GGBFS - $40 \%$ CKD) with addition of $5 \% \mathrm{SF}$ ] are graphically represented in Fig. (5). The results indicate that, the role of CKD as an alkaline activator for pozzolanic activation of GGBFS, using $5 \% \mathrm{SF}$ as an additive, is clearly distinguished due to presence of $40 \% \mathrm{CKD}$ in these mixtures. Therefore, the high pozzolanic activity of silica fume as an additive, and the increase in $\mathrm{CKD}$ content of mix M3 resulted in the production of autoclaved building product having improved mechanical characteristics, namely higher strength values and chemically combined water content. In fact, the free lime content is completely consumed at all autoclaving ages from 0.5 to 24 hours [Abo-El-Enein et al., (1990)].

By using $10 \%$ silica fume (SF) as an additive to mix M4 resulted in higher improvement of mechanical properties Fig. (6). The results of Fig. (6) 
indicate that the presence of high amounts of SF (10\%) and CKD (40\%) lead to increasing the extent of pozzolanic reaction of both GGBFS and SF (with its high pozzolanic activity); these reflected on the enhancement of compressive strength values which highly improved due to the formation of excessive amounts of hydration products (mainly as amorphous CSH) having high hydraulic character.

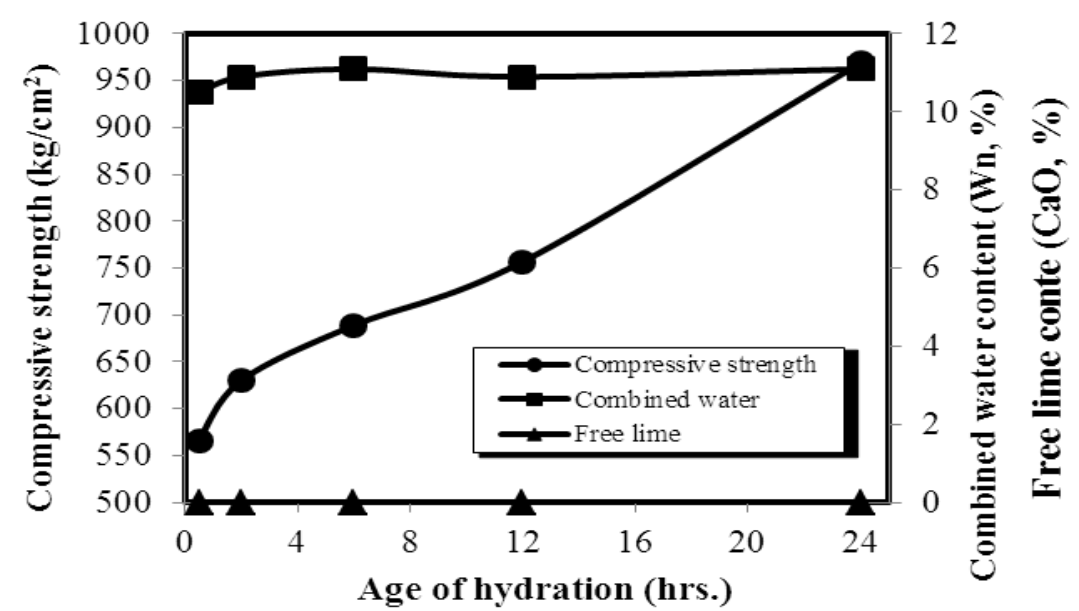

Fig(5): Compressive strength, combined water and free lime contents ofautoclaved specimens made of mix M3. 


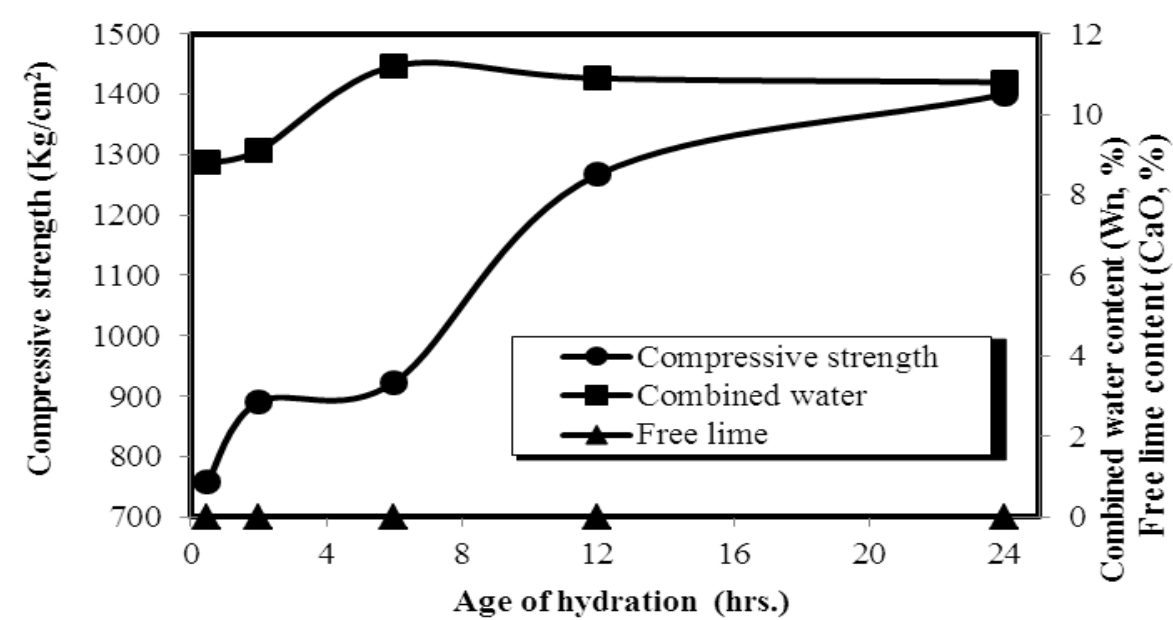

Fig(6): Compressive strength, combined water and free lime contents ofautoclaved specimens made of mix M4.

Thermogravimetric analysis: Fig. (7) shows the TGA thermograms of autoclaved specimens made of mix M4, at the hydrothermal ages of 6 and 24 hours. The results of Fig. (7) indicate that the free lime $(\mathrm{CH})$ content of the autoclave specimens was completely consumed at all ages of hydration; meanwhile, the weight loss of C-S-H phases increase with increasing age of steam curing from 6 to 24 hours. This is due to the increase of the alkali content in CKD which is sufficient for the pozzolanic reaction of GGBFS in the presence of SF as an additive.

Scanning electron microscopy: The SEM micrographs of autoclaved specimens made of mix M4 after 2 and 24 hours, are shown in Fig. (8). The SEM micrographs displayed a high dense structure composed mainly of C-S$\mathrm{H}$ phases having different degrees of crystallinity as a result of increasing SF additive to $10 \%$; this is clearly distinguished form the high extent of strength improvement the hardened specimens of mix using $10 \% \mathrm{SF}$ as an additive. 
These results are also confirmed by the results of hydration kinetics, $\left(\mathrm{W}_{\mathrm{n}}, \%\right)$ and free lime $(\mathrm{CaO}, \%)$ reported earlier in this investigation. Evidently, the role of SF as an additive in the specimens made of mixes M3 and M4 seems to be stronger activator as compared to NMK.

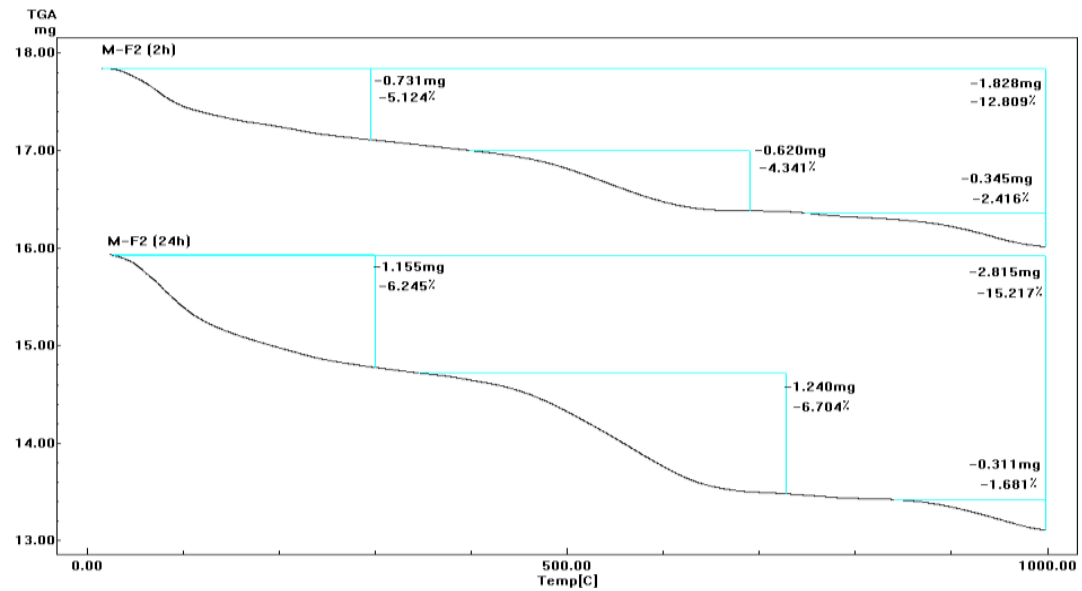

Fig(7): TGA thermograms of autoclaved specimens made of mix M4 after 6 and 24 hours.
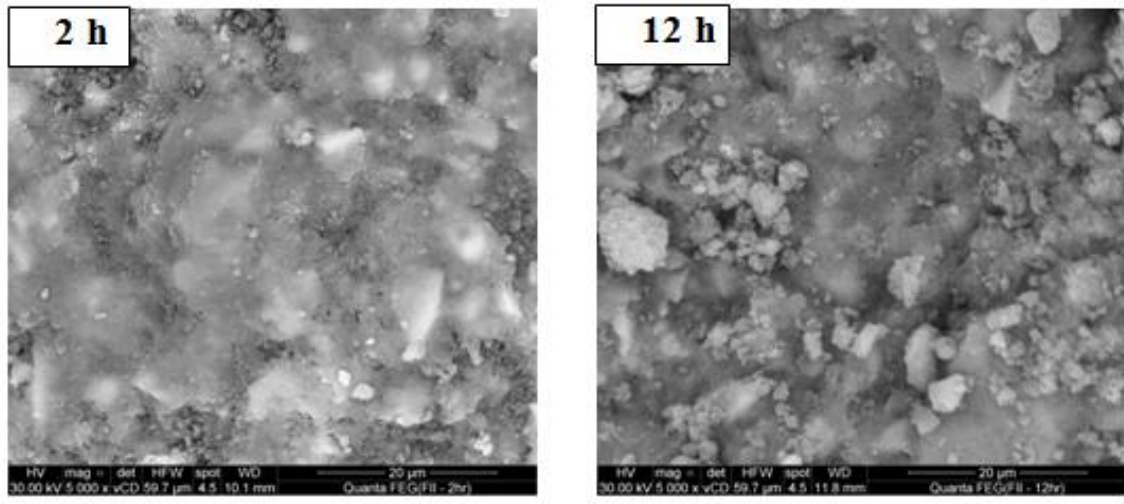

Fig(8): SEM micrographs of autoclaved specimens made of mix M4 after 2 and 12 hours. 


\section{CONCLUSIONS}

The main conclusions derived from this study can be summarized as

\section{follows:}

1. The autoclaved products obtained from the autoclaved pastes made of mixes M3 (60\% GGBFS - $40 \%$ CKD) and M4 (60\% GGBFS - $40 \%$ $\mathrm{CKD}$ ) using 5 and $10 \%$ silica fume (SF) as an additive possess high strength values as compared to those made without silica fume addition.

2. The results of this investigation revealed that these autoclaved mixes M3 and M4 resulted in the possible production of high performance building products with low cost for environmental protection (consumption of industrial solid wastes) and development. These mixes represent the optimum constitution of autoclaved building products obtained from the solid industrial wastes.

3. The autoclaved products obtained for the hardened pastes made of mixes M1 [(70 \% GGBFS - $30 \%$ CKD) with addition of $5 \% \mathrm{NMK}]$ and M2 [(70 \% GGBFS - $30 \%$ CKD) with addition of $10 \% \mathrm{NMK}]$ have reasonable improvement in strength values.

\section{REFERENCES}

Abo-El-Enein, A. S.; Amin, S. M.; Hanafi, S.; Elsokkary, M. T. and Hazem, M. M. (2014): Pozzolanic and hydraulic activity of nanometakaolin. Housing and Building National Research Center Journal, 10(1), 64-72.

Abo-El-Enein, S. A.; Hekal, E. E.; Abdel-Khalik, M., and El-Hosiny, I. (1990): Autoclaved calcium silicate hydrates: 1-rate of formation and molar composition", Il Cemento., 87, 147-160. 
ASTM C618. (2001): Standard specification for coal fly ash and raw or calcined natural Pozzolana for use as a mineral admixture in concrete. ASTM C618, Annual Book ASTM Stand 04-02, 310313.

Heikal, M.; El-Didamony, H. and Morsy M. S. (2000): Limestone-filled pozzolanic cement. Cem. Concr. Res., 30(11), 1827-1834.

Massazza, F. (2003): Lea's Chemistry of Cement and Concrete. Fourth Edition., Edward Arnold Ltd.

Morsy, S. M.; Alsayed, H. S. and Angel, M. (2010): Effect of nono-clay on mechanical properties and microstructure of ordinary Portland cement mortar. International Journal of Civil Environmental Engineering, 10(1), 21-25.

Shi, C. and Day, R. L. (1995): Acceleration of the reactivity of fly ash by chemical activation. Cem. Concr. Res., 25(1), 15-21.

Shoukry, H.; Kotkata, F. M.; Abo-El-Enein, A. S. and Morsy, S. M. (2013): Flexural strength and physical properties of fiber reinforced nanometakaolin cementitious surface compound. Construction and Building Materials, 43,453-460.

Siddique, R. and Khan, I. M. (2011): Metakaolin, supplementary cementing materials, 37, 175-230.

Singh, M. and Garg, M. (2006): Reactive Pozzolana from Indian clays their use in cement mortars. Cem. Concr. Res., 36, 1903-1907.

Srinivasu, K. D.; Krishna Sai, L. N. M. and Venkata Sairam Kumav, N. (2014): A review on use of metakaolin in cement mortar and concrete.International Journal of Innovative Research in Science, Engineering and Technology, 3 (7), 14697-14701.

Srivastava, V.; Kumar, R.; Agarwal, V. C. and Mehta, p. k. (2012): Effect of silica fume and metakaolin combination on concrete. International Journal of Civil and Structural Engineering,2(3), 893-900. 
Tseng, Y. S., Huang, C. L. and Hsu, k. c. (2005): The pozzolanic activity of a calcined waste FCC catalyst and its effect on the compressive strength of cementitious materials. Cem. Concr. Res., 35(4), 782787.

Velosa, L. A.; Rotch, F. and Velga, R. (2009): Influence of chemical and mineralogical composition of metakaolin on mortar characteristics. Acta Geodyn. Geomater, 153(6), 121-126.

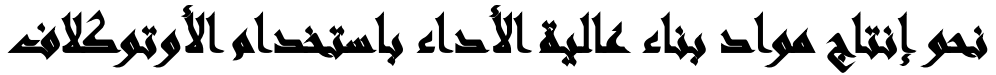

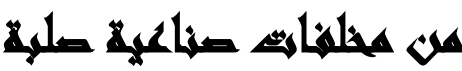

[1]

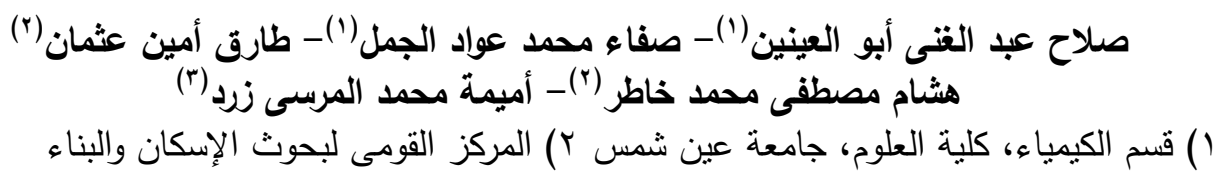

\section{(المستخلم}

يهدف هذا البحث الى دراسة إمكانية إنتاج مواد بناء عالية الأداء وذللك باستخدام بعض التصاء

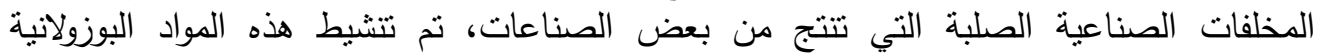
المستخدمة باستخدام تراب الأسمنت كمنشط قلوية. تم تحضير الخلطات المنات المختلفة من خبث أفرات أفران الحديد مع نراب الأسمنت بدون أو مع الضع الفافة نانوميتاكاولين اوغبار السيليكا كمواد بوزولانية.

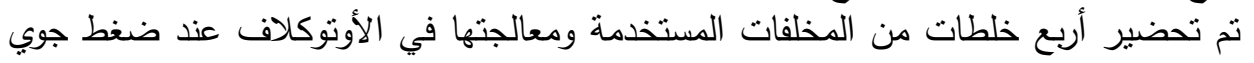

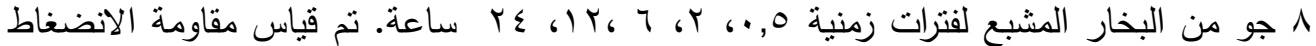
للعينات عند فترات المعالجة المختلفة. كما تم دراسة كيناتيكا التأدرت وذللك بقياس كلأ كلأ من كمية الجير

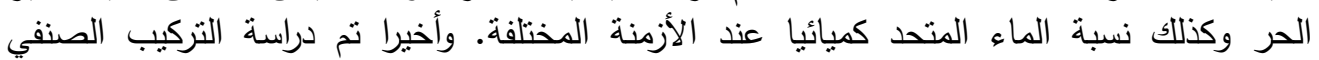

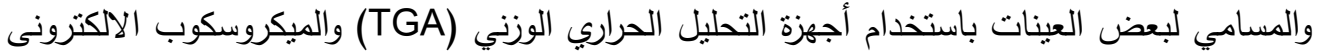

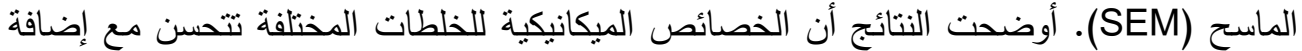

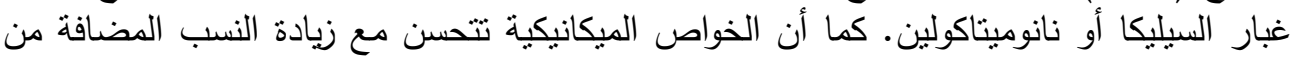

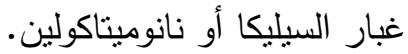

